\title{
The Palazzo Foscarini in Venice and the Celebration Honoring the Dukes of Modena (1749) in a Getty Research Institute Manuscript
}

\section{Linda Borean}

On 3 August 1749, on the occasion of the departure from Venice of Francesco III d'Este, Duke of Modena (1698-1780), a sumptuous ball was organized at the palazzo Foscarini ai Carmini. This imposing edifice, while now unembellished (fig. 1), still dominates its surroundings; it sits across from the homonymous bridge and is well known for having hosted various significant figures in European history, beginning with Henry III, King of France, when he visited Venice in 1574 (fig. 2). ${ }^{1}$

An expression of the Republic of Venice's long-standing tradition of hospitality to foreigners, private receptions were part of a broader context of a political and cultural society that, over the centuries, was unique by virtue of the precise and measured staging of civic rituals, such as the procession marking the election of the doge and religious celebrations with an unavoidable political tone: all moments necessary for solidifying, in both the patrician and the plebeian classes, loyalty and a sense of belonging to the state. ${ }^{2}$ Over the course of the Enlightenment era, Venice witnessed an increase in solemn ceremonies and performances organized by the government to pay homage to visiting sovereigns and princes and to officially welcome foreign ambassadors: from bull hunts to concerts to the regatta, which constituted the "pyramid" of celebrations, being "one of the most joyful entertainments that the Public habitually offers to Foreign Princes."” We know about these sorts of public events not only from archival documents but also from visual records, thanks to talented painters such as Luca Carlevariis, Canaletto, and Francesco Guardi, who, through the genre of the documentary vista or reportorial view, ${ }^{4}$ captured historical and newsworthy moments, giving them a specific narration.

The Republic paid for receptions that included entertainments provided by patricians in their palaces; while conceived as another manifestation of the wealth and power of an aristocratic state, in the eighteenth century these receptions became a vehicle for the exhibition of the resources, reputation, and image of the host family as well. The republican mediocritas of the Cinquecento, in fact, was supplanted by a growing desire to demonstrate the prominence of a family name, a phenomenon accompanied by a revolution in residential tastes, with the expansion of clearly defined spaces for entertainment, set aside for social life. ${ }^{5}$ Performances, concerts, and banquets in homage to illustrious guests constituted a natural corollary to these transformations.

Getty Research Journal, no. 11 (2019): 1-16 (C) 2019 Linda Borean. English translation (c) 2019 The J. Paul Getty Trust 

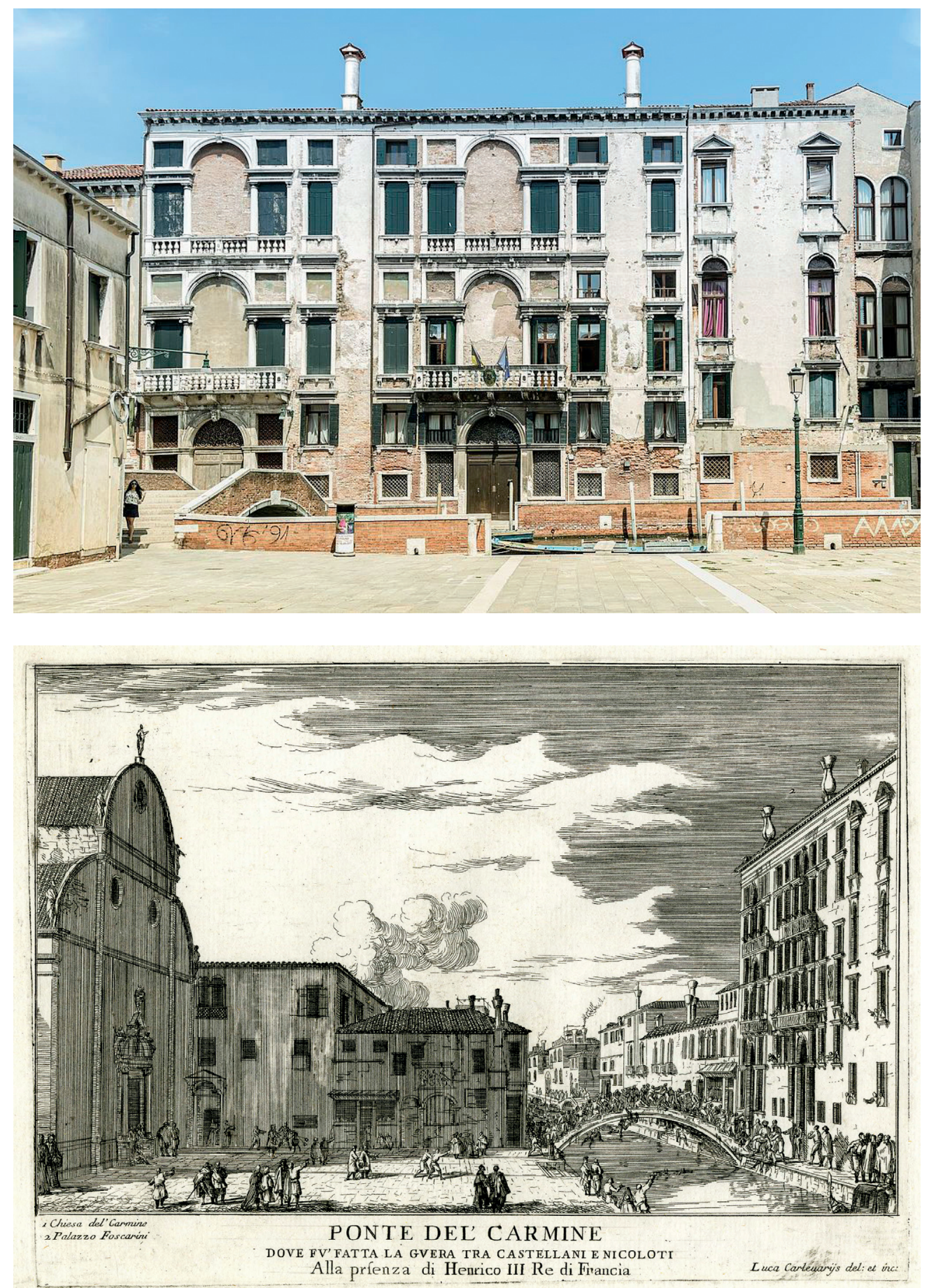

Fig. 1. Palazzo Foscarini ai Carmini. Photo by author.

Fig. 2. Luca Carlevariis (Italian, 1663-1729). Ponte del Carmine, from the series Le fabriche e vedute di Venezia (The buildings and views of Venice). Side view of the Carmini church at left with the Carmine bridge and the Palazzo Foscarini at right, etching, $208 \times 291 \mathrm{~mm}$. London, British Museum, inv. 1928,1016.50. Image: (c) The Trustees of the British Museum. 


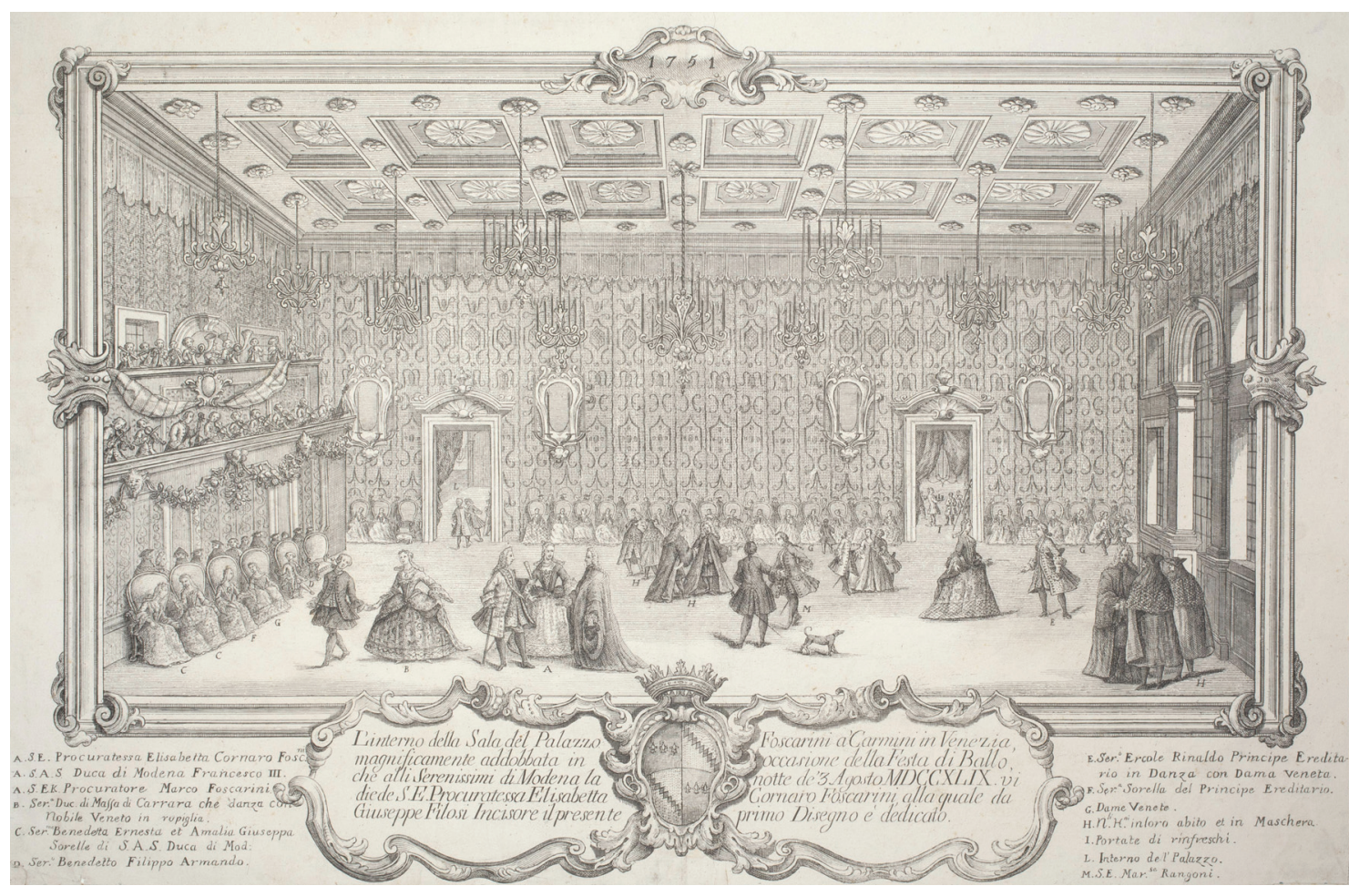

Fig. 3. Giuseppe Filosi (Italian, active ca. 1730-70). Feast at the Palazzo Foscarini in Honor of the Dukes of Modena, 3 August 1749, 1751, etching, $353 \times 538$ mm. Venice, Museo Correr, inv. n. St. Correr 5168. Image: Archivio Fotografico-Fondazione Musei Civici di Venezia.

Unlike public ceremonies, entertainments organized in the dwellings of the Venetian aristocracy are less fully documented. ${ }^{6}$ However, Pietro Gradenigo (1695-1776), ${ }^{7}$ a diarist and shrewd observer of city life at the time, could not help but comment on the reception for Francesco III d'Este at the Foscarini residence, and a concise visual memory is provided by a print dedicated to Elisabetta Corner Foscarini, ${ }^{8}$ owner of the palazzo, executed in 1751 by Giuseppe Filosi, an engraver who on other occasions was charged with depicting ceremonies and private banquets (fig. 3). ${ }^{9}$ These sources can now be supplemented by a richly detailed letter in the special collections of the Getty Research Institute. ${ }^{10}$ The intention of this article is to offer some considerations on the provenance, structure, and authorship of the manuscript, as well as a brief commentary that highlights its value as evidence to reconstruct the phenomenon of Venetian celebrations and to evoke the way interiors were arranged in eighteenth-century Venetian palaces. In this regard, it should be noted that for the Venetian context, due to the alteration of most buildings, ${ }^{11}$ a history of the display of art-understood as the interaction of architectural spaces, decoration, art objects, and people-is based predominantly on textual sources, and the palazzo Foscarini is no exception. ${ }^{12}$ 


\section{The Provenance, Structure, and Authorship}

of the Manuscript

The document is in the Eruditi Italiani letters collection, the history of which has been retraced by Luisa Ciammitti; once part of the library of Giulio Bernardino Tomitano (1761-1828), a noble from the Veneto region of northern Italy, this substantial body of epistolary works was dismantled after $1797 .{ }^{13}$ The information furnished by Ciammitti's research can now be supplemented by some additional elements related to the provenance and history of the manuscript in question. In 1821, Leopoldo Cicognara (17671834), a renowned historian and art critic who was then president of the Accademia Veneziana di Belle Arti, ${ }^{14}$ suffering financial difficulties, was forced to sell his library, one of the most esteemed in Europe..$^{15}$ In the sales catalog, arranged by Cicognara himself, the section titled Feste, ingressi, trionfi, spettacoli, funerali (Celebrations, entrances, triumphs, performances, funerals) includes item no. 1514, with an appended description that reads: "Natale Dalle Laste. Unpublished letter and manuscript that describes the celebrations given in Casa Foscarini for the Carmini in Venice at the Court of Modena in August 1749. This man of letters, along with Forcellini, were spectators at these celebrations, and the description also extends, with infinite grace, to the most minute things." ${ }^{16}$ While we cannot dismiss the possibility that two accounts of the same documents existed, and acknowledging the tortuous and unpredictable paths of the book trade, ${ }^{17}$ we might wonder whether it might be plausible to identify the letter in the Getty Research Institute with the manuscript that belonged to Cicognara, who, moreover, in 1808 married Lucia Foscarini, widow of Nicolò Filippo Foscarini (1732-1806), of the Carmini branch of the family. ${ }^{18}$

Conceived in the form of a literary topos of a letter intended for a lady of unknown identity, the reportage, dated 9 August 1749, the week after the celebrations, is composed of two parts. The first part is predominantly devoted to an account of the unfolding of the celebration, from the arrival of the guests at the palazzo shortly before midnight, to the execution of musical performances in the garden and dances in the ballroom, which went on until dawn. The second part describes a visit that reveals the building itself, with its damasked halls, painting galleries, halls of armor and studioli, small rooms covered with stucco work, velvets, and golden hearts. Cicognara's aforementioned commentary, that "the description also extends, with infinite grace, to the most minute things," captures one of the most distinctive features of the author of the manuscript, Natale Dalle Laste (1707-92). One of the most learned Latin scholars of his time ${ }^{19}$ (indeed he liked to be called Lastesius), Dalle Laste was a historiographer at the University of Padua and was friends with numerous participants in that flourishing literary period of the Republic, such as Jacopo Morelli, who was then the librarian at the Libreria Marciana. Dalle Laste's associations also extended to the most cultivated circle of Venetian patricians, whose most illustrious members then included Marco di Nicolò di San Stae (1696-1763), a man of letters and, beginning in 1735 , the official historian of the Republic as well as the beneficiary, as we shall later see, of the tremendous fortunes of the Foscarini dei Carmini 
family; he was also one of the figures involved in the 1749 reception for the Este family court. Dalle Laste participated in the latter along with Marco Forcellini (1712-94), ${ }^{20} \mathrm{a}$ former assistant in humanistic studies at the University of Padua who was in contact with Pietro Ercole Gherardi (1679-1752), deputy to Ludovico Antonio Muratori (1672-1750) in the administration of the Este library and secretary to Francesco III during the period the sovereign spent far away from Modena. ${ }^{21}$ It is very likely that the Foscarini manuscript now at the Getty originated within this web of scholarly associations and relationships.

\section{The Ball of 3 August 1749}

The 1749 festivities honoring the dukes of Este are part of the broader fabric of relationships between Venice and Francesco III; retracing them in their totality lies outside the purview of this study, but it should be noted that they were distinguished by reciprocal political appreciation. For example, on 2 June 1732 the Este prince took part in the election of doge Carlo Ruzzini (1653-1735), sitting on the Great Council among the Knights of the Golden Stole. ${ }^{22}$ Upon the death of his father, Rinaldo, in 1737, Francesco III inherited a dynasty that, in the first half of the eighteenth century, also became involved in the wars that erupted in Europe over the Polish (1733-38) and Austrian (1740-48) successions. Despite a certain diplomatic ability, honed in part through both Muratori's advice and the duke's military engagement, his domains were occupied by imperial troops during the conflict for succession to the Hapsburg throne. In June 1742, the prince had to abandon Modena along with his family, first taking refuge in Castello del Catajo in Padua and then moving on to Venice, ${ }^{23}$ where he was warmly welcomed with a reception organized by the nobleman Pietro di Alvise Foscarini (1687-1745) in the garden of his Palazzo ai Carmini. While he did not remain there continually, Francesco III retained Venice as his dynastic abode until the end of the war, when, with the Treaty of Aachen in 1748, his sovereignty was restored, albeit at a steep price. Indeed in 1746, in order to deal with military expenditures, he sold one hundred masterpieces from the Galleria Estense to Augustus III of Saxony, ${ }^{24}$ works that are now a source of pride for the Gemäldegalerie in Dresden.

In paying homage to the duke upon his departure from Venice in 1749, the Foscarini clan also revealed themselves to be one of the most hospitable families of the Venetian aristocracy, an attribute that did not escape foreign travelers. ${ }^{25}$ In 1739 , for example, Frederick Christian, son of the elector of Saxony, stayed for many months at the Carmini residence. ${ }^{26}$ However, in the case of the Este family, the hospitality offered by the Foscarini became almost a sort of tradition-one, moreover, that was greatly enjoyed by a prince like Francesco III, who loved celebrations, banquets, trips, and amusements. ${ }^{27}$ Pietro Foscarini could vaunt a more than respectable succession of public offices, resulting in 1716 in his being named the de supra procurator of St. Mark's (the second most prestigious lifetime appointment, after that of doge), and he was among the wealthiest patricians in the city, with a personal estate estimated, in 1740, at over 25,000 ducats. ${ }^{28}$ Foscarini also went to extraordinary efforts to promote theater and music, particularly when he was governor of the Ospedale della Pietà, where the chorus of young orphans 
( putte in Venetian dialect), which constituted one of the city's veritable attractions, performed during state visits or for the benefit of illustrious guests. ${ }^{29}$ In fact, Foscarini organized a concert for Francesco III at the Pietà in $1722 .{ }^{30}$ Twenty years later, Pietro again welcomed the duke upon his arrival in the city, as noted earlier, with a reception about which, to our knowledge, no documentation remains. And now we come to the celebration of 1749, which was extremely exclusive and reserved for the nobility and certain intellectuals, but where there was a notable great absence - that of Pietro Foscarini, who had died in 1745 . Near death, he had implored his wife, Elisabetta Foscarini, to pay homage to Francesco III with a "regal" reception, with no heed to expense. This was communicated in writing to Muratori by Pietro Ercole Gherardi, secretary to Francesco III, who was exasperated at having to prolong his residency in Venice-a city he cared for very littlespecifically because of the Foscarini reception. ${ }^{31}$ Cultured and brilliant, and a lover of splendor and high society, ${ }^{32}$ the widow of Pietro Foscarini did justice to her family name as well as to the aforementioned Marco Foscarini, from the San Stae branch, who had been ambassador to the papal court (1737-40) and procurator of St. Mark's, and would become doge from 1762 to 1763: in short, an undisputed leader of the conservative patrician class (fig. 4).$^{33}$ It was Marco Foscarini's political prestige that made him an ideal heir in Pietro Foscarini's eyes, and the latter, who had no male heirs, had designated him-along with his brother Alvise-a beneficiary of his enormous estate, with an obligation to move into the ancestral Carmini palazzo, taking on that name as his own surname. ${ }^{34}$ In the print by Filosi (see fig. 3), Elisabetta and Marco—who moreover were official lovers well before her widowhood-converse with Francesco III at left of center in the ballroom, which is clad in crimson velvet (so Dalle Laste notes); they create a focal point for the scene and thus demand our attention, while the hereditary prince, Ercole, and his wife, Maria Teresa Cybo Malaspina, spin about in minuets to the sound of the music of the orchestra, arranged to the left and beneath which the duke's sisters sit in a "procession." 35

The ball itself, according to customs of the time, was preceded by the execution of a cantata, a type of musical performance very similar to an opera, but eulogistic and celebratory in nature. ${ }^{36}$ Titled La Pace (Peace) and composed for four voices, the serenade performed on 3 August 1749 was, in fact, a replica with variations of a song set to music and performed at the 1742 reception, ${ }^{37}$ based on a libretto by Gasparo Gozzi (1713-86), a well-known intellectual of the time who had close ties to Marco Foscarini: ${ }^{38}$ beneath the gaze of Peace, Adria and Proteo, maritime divinities who for centuries had been used for scenes of the Republic, return the sovereign (Francesco III) to the river Panaro in Modena, which traverses his domains. ${ }^{39}$ Dalle Laste gives a detailed account of the interpreters, including some comments about their performances. Two highly regarded opera virtuosos-Giovanni Carestini (ca. 1705-60), one of the most famous castrati of the time, and Francesca Cuzzoni (ca. 1691-1772) - took on the roles of Adria and Proteo. ${ }^{40}$ An acclaimed soprano, accustomed to receiving extraordinary compensation, but forbidding in nature, Cuzzoni had already had a remarkable musical career with the Royal Academy of Music at King's Theatre Haymarket in London, then directed by 


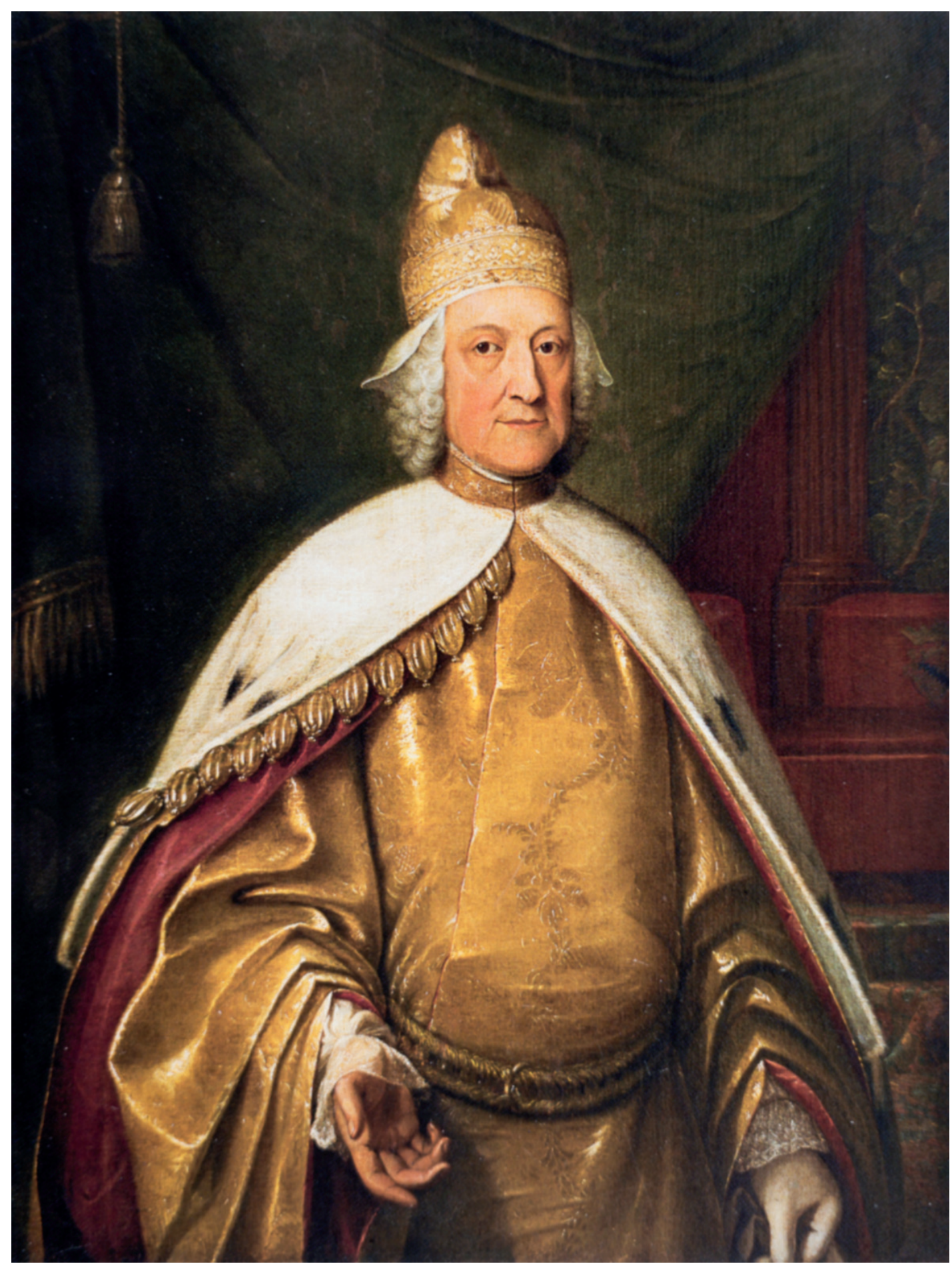

Fig. 4. Nazario Nazzari (Italian, 1724-after 1793). Portrait of the Doge Marco Foscarini, 1763, oil on canvas, $126 \times 94 \mathrm{~cm}$. Venezia, Museo Correr, Inv. Cl. I Nr. 230. Photo by author. 
George Frideric Handel (1685-1759). She was clearly no longer very young and, according to Lastesius, it was surprising to "hear one only slightly younger than a septuagenarian sing with a jovial, clear and high voice, which resounded throughout the entire garden." In fact, the serenade was held in the garden of the palazzo, a veritable natural theater, Dalle Laste explains, "because of the loosely arranged citrus trees, the marvels clad in green, the various flowers and plays of junipers and boxwood, and the vague and well-intended illumination.” This was the garden where Marco Foscarini had a loggia built to accommodate his famous library, in the wake of the recent widespread tendency in Venetian society to separate the library from the main residence, setting aside a small adjacent building for this purpose. ${ }^{41}$

\section{The Decoration, Furnishings, and Collections of Palazzo Foscarini}

Upon the conclusion of the cantata, at four in the morning, Dalle Laste left, along with his companion Forcellini, to visit the palazzo and, aware of the short time at his disposal, he decided not to "defraud his eyes and mind" looking at the reception halls and dressing rooms that twisted and turned in a sort of infinite maze. The building seemed a veritable palace of delights with its sparkling furnishings, frescoed friezes, paintings, statues, stuccowork, tapestries, boiseries, ebony chests, and silver bases: all illuminated by precious chiocche, glass and crystal chandeliers, one of the novelties that the glassmaker Giuseppe Briati introduced in the eighteenth century. ${ }^{42}$ The lighting component naturally played a fundamental role not only in the interiors but also outside, starting with the building's facade, which was adorned with forty torches that gave the effect of candlelight, probably not very dissimilar to what Francesco Guardi captures in The Nocturnal Good Friday Procession in Piazza San Marco (1755; Oxford, Ashmolean Museum). ${ }^{43}$

Dalle Laste's letter provides an interesting complement to the inventory of assets in Palazzo Foscarini, dated 1 April 1758 and related to the furnishings connected to a trust (and thus unalienable), set up by Pietro Foscarini, who deemed them necessary "for use and for the adornment of the most excellent Foscarini house." ${ }^{44}$ Dalle Laste describes colorful damasks in Rococo taste, velvet armchairs with carved and gilded flowers, mirrors, tables of marble, and colored stones; his language deliberately conveys the quantity but also the quality of the furnishings, almost as if he were attempting to defend the interiors of the palazzo Foscarini, which the Frenchman Charles de Brosses (1709-77) had judged sternly during his trip to Venice in the summer of 1739: "there are no less than two hundred pieces in the apartment, all overladen with richness, just in the Foscarini palace, but there is not a single cabinet or armchair where one can sit down, due to the delicacy of the carvings." 45 And then the effort was not even rewarded by the collection of paintings exhibited "without much taste." But in 1749, Elisabetta Foscarini had provided for improvements to the exposition of artworks, moving the most prestigious paintings into the palazzo's main gallery, which had been especially upholstered in leather with golden heart decorations. ${ }^{46}$ Dalle Laste admired them in this renovated context and focused in particular on the quality of the paintings: 
Many beautiful paintings, many intimations of size, authorship, idea. At a glance we wanted to devour them all. We began to enjoy them in order: but curiosity and wonder then broke all laws. Here was a place to stop, but time and other things put pressure on us. We left them in our hearts moving on to the other room; and our eye turning back once or twice, and to this and to that painting, deigning barely a glance to four large silver candelabras that sufficed to illuminate the gallery in order to not encumber it with lamps, and on our short visit counting thirty-six large porcelain vases that formed around us a cordon on the floor.

From the 1758 inventory we can glean that the installation of the painting gallery followed a practice widespread in the modern era, namely "completely adorning the walls with paintings," following the format of the works and the search for effects of symmetry. ${ }^{47}$ Even while "submerged" by the paintings, Dalle Laste stops to comment on a series with episodes from the life of Christ and the Virgin, attributed to "Luca d'Olanda," namely Lucas van Leyden (1494-1533), celebrating the works' "truthfulness and simplicity of nature": a judgment that seems to anticipate the opinion expressed years later by Anton Maria Zanetti the Younger (1706-78), regarding certain masters of the Venetian Quattrocento, such as Vittore Carpaccio (ca. 1465-1526). ${ }^{48}$ While documents attest to this Dutch master's favor among Venetian collectors in Dalle Laste's circle, such as the Farsetti, ${ }^{49}$ it is very likely that the paintings recorded in his name were copies executed in the late sixteenth and seventeenth centuries, a period during which there was a strong revival of interest in Lucas van Leyden's work. ${ }^{50}$

In addition to the gallery, Dalle Laste's remarks dwelled on the hall of armor and the apartment with tapestries. The former seemed to him like an evocative military sancta sanctorum, a space where memories of a glorious past mix with nostalgia, in keeping with a commonplace tradition in residential architecture in Venice, at least beginning in the late sixteenth century. ${ }^{51}$ At the center of the hall a marble bust of Giacomo di Alvise Foscarini $(1523-1602)^{52}$ dominated; he was a valiant warlord who fought against the Turks and the personal bodyguard of Henry III of France during his 1574 visit to Venice. He was depicted with a crown, armor, swords, and halberds, illuminated "with wonderful attention," creating an atmosphere of "horror" that Dalle Laste deemed perfect for these military garments. The hall of tapestries, for its part, contained nine woolen and silk tapestries, illuminated by precious lamps that were meant to heighten the brilliance of the colors; they depicted nine different episodes of Gerusalemme Liberata, "which through the spirit of the drawing and actions... are no less acclaimed now in Venice than they were, before, in Rome," as remarked by Dalle Laste. The Foscarini inventory of 1758 enumerates fifteen tapestries illustrating stories inferred from the renowned poem by Torquato Tasso (1544-95), and which, at the time, were stored in cabinets (indicating occasional use as well as a rotation exhibition of the series) but used on official occasions to adorn the portego and a room on the upper floor. ${ }^{53}$ The precise correspondence of the number 


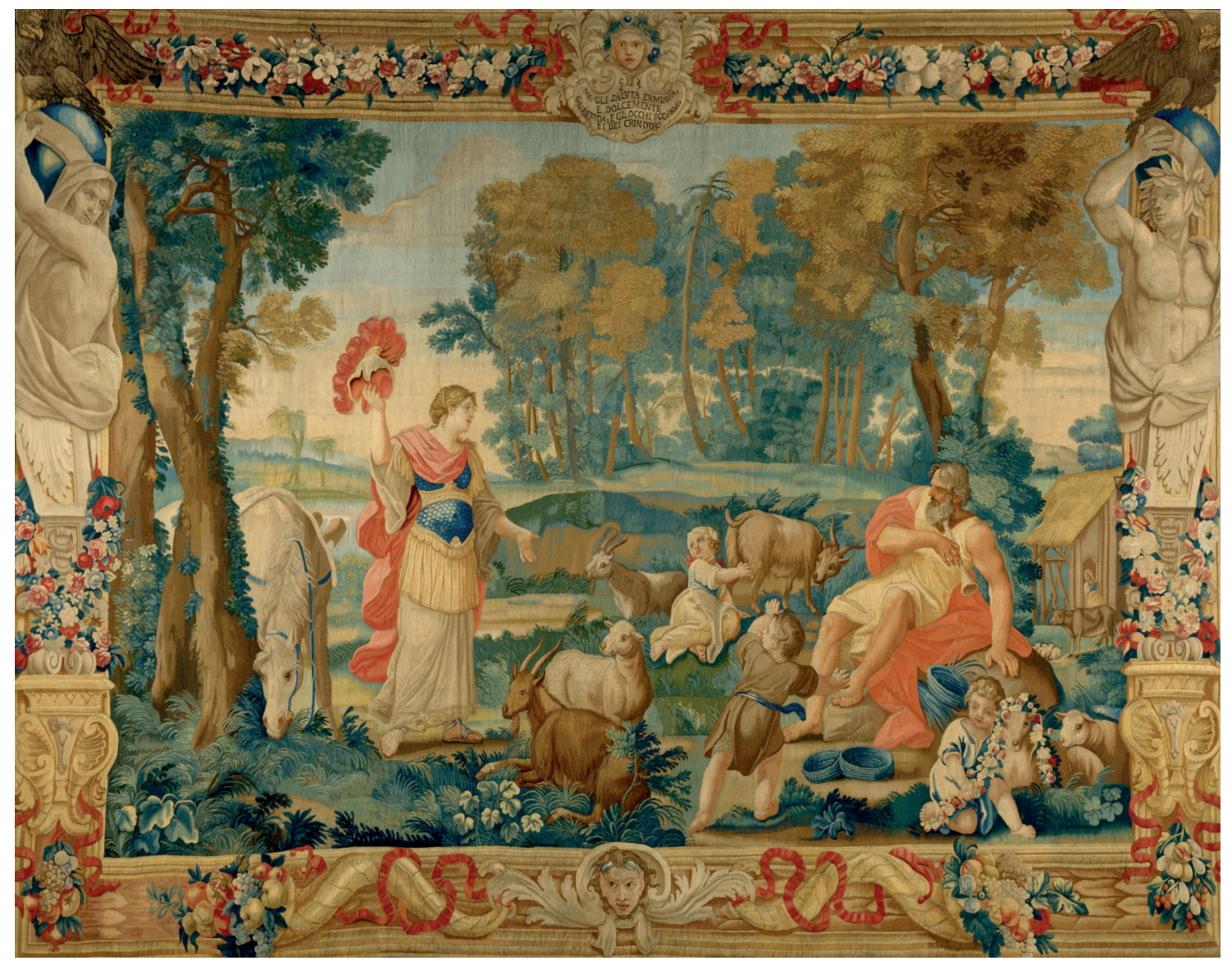

Fig. 5. Domenico Paradisi (Italian, active 1689-1721), designer. Erminia and the Shepherd, designed ca. 1689-93, woven 1732-39, tapestry (wool and silk), 363.2 × 457.2 cm. New York, Metropolitan Museum of Art, inv. no. 92.1.17. 
of scenes (fifteen), the dimensions, and the inclusion of verses of Tasso's poem to accompany every episode allow us to hypothesize that the Foscarinis had come into possession of the celebrated series of tapestries dedicated to Gerusalemme Liberata, commissioned by the Venetian cardinal Pietro Ottoboni (1667-1740). A grandnephew of Pope Alexander VIII (1610-91), Ottoboni was a man of refined literary culture as well as a lover of splendor and good taste who was remembered for his brilliant career as a patron of the arts and a protector of artists. The tapestries depicting episodes from Tasso's poem constitute one of the last and most important acts of patronage by the powerful cardinal. The series, conceived to decorate Palazzo della Cancelleria in Rome, then the official residence of the Ottoboni family, ${ }^{54}$ was woven, beginning in 1732 , in the papal workshop in San Michele a Ripa, under the supervision of Pietro Ferloni, working from faux tapestries painted on canvas by the Venetian master Domenico Paradisi (1660-1727).$^{55}$ Without conjecturing the existence of two series, a hypothesis deemed implausible by scholars, ${ }^{56}$ the Gerusalemme Liberata tapestries must have been sold to pay Ottoboni's debts, which amounted to more than 170,000 scudi, after his death on 28 February $1740 .{ }^{57}$ The purchasers most likely included Marco Foscarini, who at the time was the ambassador to the court of Pope Clement XII. Unfortunately, when he was later elected doge, in 1762, the estate that Marco had inherited from Pietro Foscarini had already been severely depleted by his innumerable debts, created by political responsibilities and social commitments. These financial problems would have been aggravated by the death of Elisabetta Foscarini in 1778 , necessitating the sale of furniture, books, and artworks. ${ }^{58}$ Amid this predicament, the series of Gerusalemme Liberata tapestries would have been sold on the international market, becoming dispersed across various institutions, including the Metropolitan Museum of Art in New York (fig. 5) and the San Francisco Opera House. ${ }^{59}$

\section{Epilogue}

With the arrival of dawn's early light, the celebration came to an end; in his farewell addressed to the letter's unknown recipient, Dalle Laste takes stock of the night spent amid the rooms of an enchanted palazzo of the type described in the poetry of Torquato Tasso or Ludovico Ariosto. Along with his travel companion, the philosopher comes to the conclusion that

that place cannot be worthily appreciated by someone who admires its parts, but only by someone who understands the overall idea. In fact, one could know, for example, that five thousand lamps burn, that the silver exhibited through the rooms amounted to approximately thirty thousand lire, that the furnishings were even more precious; but the order, the arrangement, the correspondence, and the intelligence of the way the parts relate to each other and with the whole cannot be appreciated and enjoyed except in a metaphysical sense. And here, precisely, in our opinion, lay the rare and wonderful aspect of that palace and that celebration, which was not a work of lowly creation, but of a vast intellect 
and the finest understanding. And this, Madam, is what cannot be expressed in a letter. I have written you everything but I have not told you the best. You need to see it with your own eyes, then contemplate it with your mind.

The writer explicitly states the limited evocative power of his verbal account in conveying a complex combination of architecture, ornamentation, and art collections, capable of transforming physical spaces into sites where the senses and intellect are exalted. But for us, his missive remains an extraordinary document for the history of Venetian culture and society in the eighteenth century.

\section{Linda Borean is Professor of History of Art at the University of Udine.}

Notes This essay was translated from the Italian by Marguerite Shore.

1. The engraving by Luca Carlevariis $(208 \times 291 \mathrm{~mm})$ is part of the collection Le Fabriche e le Vedute di Venezia disegnate, poste in prospettiva et intagliate da Luca Carlevariis, Venice 1703. It depicts the Carmine bridge, across from the palazzo Foscarini, which is visible on the right in figure 2 and served as a place of combat between two working-class factions in Venice-the nicolotti and the castellani-witnessed by Henry III in 1574, while he was a guest at the palazzo. Dario Succi, La Serenissima nello specchio di rame. Splendore di una civiltà figurativa del Settecento. L'opera completa dei grandi maestri veneti (Cecchetto Prior Alto Antiquariato: Castelfranco Veneto, 2013), 34.

2. Lina Padoan Urban, "Il carnevale veneziano," in Storia della cultura veneta. Il Settecento, 5/I, ed. Manlio Pastore Stocchi (Vicenza: Neri Pozza, 1985), 641.

3. Giovanni Battista Albrizzi, Forestiere illuminato intorno le cose più rare, e curiose, antiche, $e$ moderne della città di Venezia (Venice: Albrizzi, 1740), 242-43.

4. This is the term coined by Peter Bjorn Kerber, Eyewitness Views: Making History in Eighteenth Century Europe (Los Angeles: J. Paul Getty Museum, 2017), 1, to describe paintings of views illustrating contemporary historical events, chosen on the basis of their artistic quality, while works of purely documentary value are excluded from the repertoire collected in the publication.

5. Isabella Palumbo Fossati Casa, "Gli interni della casa veneziana nel Settecento: Continuità e trasformazioni," in L'uso dello spazio privato nell'età dell'Illuminismo, ed. Giorgio Simoncini (Florence: Leo Olschki, 1995), 165-73.

6. Lina Padoan Urban, Banchetti veneziani dal Rinascimento al 1797 (Venice: Strategy \& People, 2007), 87-104.

7. Pietro Gradenigo, Notatori, Venice, Museo Correr, Mss. Gradenigo-Dolfin, I, c. 43, 3 agosto 1749.

8. The inscription placed at the center of the print, inside a mixtilinear frame, reads: "The interior of the Hall of Palazzo Foscarini a' Carmini in Venice, magnificently decorated on the occasion of the Ball, given for the Serenissimi of Modena on the night of 3 August MDCCXLIX by S.E.Procuratessa Elisabetta Cornaro Foscarini, to whom this first Drawing is dedicated by Giuseppe Filosi Engraver."

9. Venice, Museo Correr, St.Correr 5168 , etching, $353 \times 538 \mathrm{~mm}$. Also by his hand, for example, is a print commemorating the celebration given in 1716 at Palazzo Mocenigo, in honor of Frederick Augustus of Saxony, and one commemorating the solemn marriage of Caterina Loredan and Giovanni Mocenigo in 1752. See Stefania Mason, “Il caso Mocenigo," Il collezionismo d'arte a Venezia. Il Settecento, ed. Linda Borean and Stefania Mason (Venice: Marsilio, 2007), 173-74; Feliciano Benvenuti, "La città dei piaseri," in Storia di Venezia. Dalle origini alla caduta della Serenissima. VIII. L'ultima fase della Serenissima, ed. Pietro Del Negro and Paolo Preto (Rome: Treccani, 1998), 741. Filosi, whose biography has many gaps, worked above all in the field of illustrated publications, furnishing engravings for prestigious businesses, such as the volume Vedute delle ville e d'altri luoghi della Toscana, published in Florence, edited by Giuseppe Allegrini, a project 
on which Giambattista Piranesi also participated. Regarding this undertaking, see Dario Succi, Da Carlevarijs ai Tiepolo. Incisori veneti e friulani del Settecento (Venice: Arsenale Editrice, 1983), 181, 292, 480-81; and Succi, La Sevenissima nello specchio di rame, 258, 378. Also see Flaminia Gennari Santori, "Filosi Giuseppe," in Dizionario Biografico degli Italiani, 48 (Rome: Treccani, 1997), 3-5.

10. Los Angeles, Getty Research Institute, Eruditi Italiani letters, acc. no. 850511, box 57, vol. 227 , n. 42 , cc. unnumbered.

11. Regarding this aspect, see the always indispensable publication of Alvise Zorzi, Venezia scomparsa (Milan: Electa, 1984).

12. Regarding the architectural developments of the palazzo Foscarini, see Elena Bassi, Palazzi di Venezia (Venice: Arsenale Editrice, 1976), 342-45; and Eva Casiroli and Dario Zanverdiani, "Il casino dei Vendramin e i giardini dei Foscarini e Berlendis ai Carmini," in Taccuino: Iconografia, misura, disegno, ed. Vincenzo Lucchese and Dario Zanverdiani (Milan: Città Studio, 1993), 23-35. Specifically regarding the nature of literary sources for the reconstruction of Venetian interiors in the modern era, see Linda Borean, The Display of Art Collections in Venice (c. 1650-1850), in 34th International Congress CIHA Proceedings, Beijing 2017, forthcoming.

13. Luisa Ciammitti, "Reassembling a Dismembered Archive: Tomitano's Eruditi Italiani Archive at the Getty Research Institute," Getty Research Journal, no. 5 (2013): 41-54.

14. Giandomenico Romanelli, "Leopoldo Cicognara," in Dizionario Biografico degli Italiani, 25 (Rome: Treccani, 1981), 421-28.

15. Barbara Steindl, “Collezionare libri d'arte: La biblioteca di Leopoldo Cicognara e il suo sistema bibliografico," in Riflessi del collezionismo tra bilanci critici e nuovi contributi, ed. Giovanna Perini Folesani and Anna Maria Ambrosini Massari (Florence: Leo Olschki, 2014), 242-43. For the manuscripts and codices collected by Cicognara, see Elena Granuzzo, "Leopoldo Cicognara e la sua Biblioteca: Formazione e significato di una collezione (I)," La Bibliofilia, CXIV, n. 2 (2012): 264-65. A true bibliophile, Cicognara would have wanted to publish a "small additional catalogue" that would have included "some valuable mementos of extraordinary rarities, especially regarding Celebrations, Spectacles, Emblems.”

16. Catalogo ragionato dei libri d'arte e d'antichità posseduti dal conte Leopoldo Cicognara, I (Pisa: Presso Niccolò Capurro, 1821), no. 1514 .

17. The Cicognara manuscript could have been turned over separately, before the Cicognara collection moved to the Biblioteca Apostolica Vaticana. I would like to thank Dr. Paolo Vian, Director of the Department of Manuscripts at the Biblioteca Apostolica Vaticana, for his help and generous exchange of ideas.

18. Paolo Preto, "Nicolò Filippo Foscarini," in Dizionario Biografico degli Italiani, 49 (Rome: Treccani, 1997), 405-8. Regarding the complicated events of the Foscarini family during the final years of the Republic, refer to Renzo Derosas, "La crisi del patriziato come crisi del sistema familiare. I Foscarini ai Carmini nel secondo Settecento," in Studi veneti offerti a Gaetano Cozzi, ed. Gino Benzoni (Rome: Il Cardo, 1992), 309-31, esp.320-31.

19. Paolo Preto, “Natale Dalle Laste," in Dizionario Biografico degli Italiani, 32 (Rome: Treccani, 1986), 101-3.

20. Guido Fagioli Vercellone, "Marco Forcellini," in Dizionario Biografico degli Italiani, 48 (Rome: Treccani, 1997), 790-92.

21. Edizione nazionale del carteggio di Ludovico Antonio Muratori, vol. 20, Carteggio con Pietro Ercole Gherardi, ed. Guido Pugliese (Florence: Olschki, 1982), 8, 447 (no. 464, letter of 10 August 1748). By December 1743, Gherardi was in touch with Marco Foscarini, whose "good and clean library" he would then visit. Edizione nazionale, 191 (no. 216, letter of 14 December 1743). The correspondence with Muratori is predominantly pragmatic in nature and pertains above all to editorial problems and research.

22. Andrea da Mosto, I dogi di Venezia (Giunti: Florence, 2003), 472. 
23. Carlo Previdi, Francesco III d'Este (Modena, 1698-Varese, 1780). Successi, errori, glorie, scandali ed altre vicende nella vita di un sovrano, grande riformista europeo (Edizioni il Fiorino: Modena, 2014), 74-75.

24. Johannes Winkler, La vendita di Dresda (Modena: Panini, 1989), 31-57.

25. Jean Georgelin, Venise au siècle des lumières (La Haye: Mouton, 1978), 491-92.

26. Deborah Howard, "Pietro Foscarini e l'altar maggiore della chiesa della Pietà a Venezia," Arte Veneta, 45 (1993): 62-69. According to Francesco III's secretary, the marbles for the altar would have been paid for by the Estensi. See Edizione nazionale, 512 (no. 515, letter of 9 August 1749).

27. Previdi, Francesco III, 62-63.

28. Da Mosto, I dogi, 497.

29. Eleanor Selfridge-Field, A New Chronology of Venetian Opera and Related Genres 1660-1760 (Stanford, CA: Stanford University Press, 2007), 645-46; Laura Moretti, "Usi dello spazio e allestimenti temporanei nella chiesa di San Lazzaro dei Mendicanti durante Sei e Settecento," in La chiesa e l'ospedale di San Lazzaro dei Mendicanti. Arte, beneficenza, cura, devozione, educazione, ed. Alexandra Bamji, Linda Borean, and Laura Moretti (Marcianum Press: Venice, 2015), 223-40; and Kerber, Eyewitness Views, 81.

30. Selfridge-Field, A New Chronology, 474, 644.

31. Edizione nazionale, 506 (no. 510, letter of 5 July 1749): “Before dying, Procurator Foscarini entrusted and through verbal request instructed his wife to communicate that conversation or nocturnal vigil to the court of Modena, which he could not execute, his death being imminent, and so he passed on to the other world, content that the promise made to him by his wife would be carried out. In fact, he magnificently adorned the rooms, halls and the entire house. It is said that the intended recreation of games, music and refreshments would not take place until the following 2 or 3 August. This additional interruption was required in order to extend the dwelling in this town where, the more I stay, the more it annoys me. I have gotten to know it too well.” On 26 July 1749 (Edizione nazionale, 510, letter no. 514), Gherardi commented as follows, scandalized: "Ten thousand pounds of wax (it is not a fantasy, no) are ordered and prepared to illuminate the house, inside and out. With winds and a thousand lire more, it would have been possible to help so many of the poor in Venice. She thinks to spend the remainder on music, players, refreshments, embellished books, etc."

32. In 1767 , the diarist Pietro Gradenigo chose to record that on the occasion of the regatta in honor of Charles Eugene, Duke of Würtenberg, Foscarini paid to adorn a peota (pleasure boat). Notizie d'arte tratte dai notatori e dagli annali del N.H. Pietro Gradenigo, ed. Lina Livan (Venice: La Reale Deputazione Editrice, 1942), 155.

33. Piero Del Negro, "Marco Foscarini," in Dizionario Biografico degli Italiani, 49 (Rome: Treccani, 1997), 390-94.

34. See Derosas, "La crisi del patriziato," 314-16.

35. The print contains a legend, an element quite uncommon in this genre of representation, that makes it possible to identify the members of the Este dynasty present at the ceremony: Benedetta Ernesta and Amalia Giuseppa, the duke's sisters; Benedetto Filippo Armando, the duke's second-born child, and finally the hereditary prince, Ercole Rinaldo, with his consort, Maria Teresa Cybo Malaspina, Duchess of Massa and Carrara. Carlotta Aglae d'Orléans, the stormy wife of Francesco III, instead, is absent, having temporarily returned to the court of Paris.

36. Michael Talbot, “The Serenata in Eighteenth-Century Venice," Royal Musical Association Research Chronicle, no. 18 (1982): 12.

37. Selfridge-Field, A New Chronology, 615 .

38. Gozzi was one of the intellectuals who collaborated on the preparation of Della Letteratura veneziana, published in 1752, where Foscarini proposes a new history of Venice, based on its complex and layered civic culture. Gasparo Gozzi, Lettere, ed. Fabio Soldini (Parma: Ugo Guanda Editore, 1999), X-XI. 
39. Anna Laura Bellina, "La famiglia Gozzi all'opera," in Gasparo Gozzi e la sua famiglia (17131786), ed. Manlio Pastore Stocchi and Gilberto Pizzamiglio (Venice: Istituto Veneto di Scienze, Lettere e Arti, 2015), 131.

40. Bianca Maria Antolini, "Francesca Cuzzoni,” in Dizionario Biografico degli Italiani, 31 (Rome: Treccani, 1985), 554-56; Francesco Degrada, “Giovanni Carestini,” in Dizionario Biografico degli Italiani, 20 (Rome: Treccani, 1977), 83-85. Caricatures of both exist, executed by Marco Ricci and Anton Maria Zanetti. Enrico Lucchese, L'Album di caricature di Anton Maria Zanetti alla Fondazione Giorgio Cini (Venice: Fondazione Cini, 2015), 117-18.

41. Dorit Raines, "La biblioteca-museo patrizia e il suo capitale sociale," in Arte, storia, cultura e musica in Friuli nell'età del Tiepolo, ed. Caterina Furlan and Giuseppe Pavanello (Udine: Forum, 1998), 63-84. The library still exists and has been adapted to be a private residence.

42. Giuseppe Boerio, Dizionario del dialetto veneziano (Venice: Reale Tipografia di Giovanni Cecchini, 1856), 167 and 377. “Chioca de cristal” indicates chandelier, namely “devices serving to deliver light.” Elena Bassi, “Giuseppe Briati,” in Dizionario Biografico degli Italiani, 14 (Rome: Treccani, 1972), 217-18. Briati (1686-1772), a custodian of glassmakers' art, obtained from the government the privilege to manufacture crystal of the type made in Bohemia. He established an important factory that was located next to the Church of the Carmini, along the embankment that still bears his name, a short distance from the palazzo Foscarini. The Briati glassworks became the official supplier for state banquets and in 1739-40 was visited by Frederick Christian of Saxony. Padoan Urban, Banchetti veneziani, 90.

43. Kerber, Eyewitness Views, 145-49.

44. The 1758 inventory of the palazzo Foscarini ai Carmini is published in Linda Borean and Stefania Mason, eds., Il collezionismo d'arte a Venezia. Il Settecento (Venice: Marsilio, 2007), 340-45.

45. Charles de Brosses, Lettres familières écrites d'Italie à quelques amis en 1739 et 1740 (Paris: Poulet-Malassis et De Broise, 1858), 136, letter of 26 August 1739.

46. Linda Borean, "Dalla galleria al museo: Un viaggio attraverso pitture, disegni e stampe nel collezionismo veneziano del Settecento," in Borean and Mason, Il collezionismo, 12.

47. Gail Feigenbaum, "Introduction: Art and Display in Principle and in Practice," in Display of Art in the Roman Palaces 1550-1750, ed. Gail Feigenbaum with Francesco Freddolini (Los Angeles: Getty Research Institute, 2014), 1-24.

48. Giovanni Previtali, La fortuna dei primitivi. Dal Vasari ai neoclassici (Turin: Giulio Einaudi Editore, 1964), 97.

49. In 1764, Dalle Laste had published an erudite booklet on the collection of Filippo Farsetti (1703-74), De Museo Philippi Farsetti (1764), which was frequented by young people and promising artists, including Antonio Canova. Sergej Androsov, La Collezione Farsetti del Museo Ermitage (Pontedera: Bandecchi and Vivaldi, 2005), 39.

50. Elise Lawton Smith, The Paintings of Lucas van Leyden: A New Appraisal, with Catalogue Raisonné (Columbia: University of Missouri Press, 1992), 82-83.

51. Francesco Sansovino, Venetia città nobilissima et singolare (Venetia: Appresso Iacomo Sansovino, 1581), 142v. Also see Isabella Palumbo Fossati Casa, Intérieurs Vénitiens à la Renaissance. Maisons, societé et culture (Paris: Michel De Maule, 2012), 245-47.

52. Roberto Zago, “Giacomo Foscarini,” in Dizionario Biografico degli Italiani, 49 (Rome: Treccani, 1997), 365-70.

53. Regarding the uses of the portego, see Margaret A. Morse, "The Venetian Portego: Family Piety and Public Prestige," in The Early Modern Italian Domestic Interior, 1400-1700. Objects, Spaces, Domesticities, ed. Erin J. Campbell, Stephanie R. Miller, and Elizabeth Carroll Consavari (Farnham: Ashgate, 2013), 92-94.

54. Edward J. Olszewski, "The Tapestry Collection of the Cardinal Pietro Ottoboni," Apollo 116, no. 246 (1982): 103-11. 
55. Edward J. Olszewski, The Inventory of Paintings of Cardinal Pietro Ottoboni (1667-1740) (New York: Peter Lang Publishing, 2004), 31-32. Regarding Ferloni, see the editorial entry “Pietro Ferloni," in Dizionario Biografico degli Italiani, 46 (Rome: Treccani, 1996), 321-23.

56. Edith A. Standen, “Tapestries for a Cardinal-Nephew: A Roman Set Illustrating Tasso's Gerusalemme Liberata," Metropolitan Museum Journal, 16 (1981): 147-64.

57. Olszewski, The Inventory of Paintings, 8-10, 212-15; Jeanne Bignami Odier, Premières recherches surle fonds Ottoboni (Rome: Biblioteca Apostolica Vaticana, 1966), 13-21.

58. Derosas, “La crisi del patriziato," 321-26.

59. Standen, “Tapestries for a Cardinal-Nephew," 154 and 163-64: certain tapestries were purchased by the tenth Duke of Hamilton (1767-1852). In an expertise issued by the Accademia di Belle Arti di Venezia in 1833 (signed by Odorico Politi and Luigi Zandomeneghi), regarding the request to export the tapestries in question, emphasis is given to the excellent quality of the items and their perfect state of preservation, guaranteed by the use of coltrinoni, that is, protective curtains, noted in the Foscarini inventory of 1758 . I would like to thank Isabella Cecchini for pointing this out. 